\title{
Mapping press ideology. A methodological proposal to systematise the analysis of political ideologies in newspapers
}

Jucinara Schena*, Núria Almiron**, Antonio Pineda***

\author{
*Universitat Pompeu Fabra, Spain \\ **Universitat Pompeu Fabra, Spain \\ ***Universidad de Sevilla, Spain
}

\begin{abstract}
Ideology and political ideologies in general have been addressed both from theoretical and applied perspectives by media and communication scholars in an attempt to reveal whether pluralism is present or absent in the media. However, the complexity of such a task has proven to be high as well as very problematic. The efforts to systematise the study of ideology in the media in order to make it objective and systematic have been scarce. This paper tries to contribute to such systematising by providing a method to analyse political ideologies in the media that aims to be objective and replicable in the political context of Western democracies. Our work was inspired by previous studies that were mostly conducted in the field of political sciences and political communication. The main goal of this paper is to reach a deeper comprehension of ideology, in general, and political ideology in particular, and to conceptualise a method that aims to be instrumental in the analysis of the media from the viewpoint of political ideologies but without being restricted by traditional labels that may reproduce cultural biases. The theoretical-analytical method here suggested addresses ideologies in newspapers to identify worldviews according to four general values: individualism, communitarianism, egalitarianism and elitism.
\end{abstract}

Keywords: ideology, political ideologies, media, pluralism, press and politics

\section{Introduction}

The media is one of the main tools by means of which ideologies, the systems of meanings that helps to define and explain the world, spread and perpetuate. Critical scholars have long discussed how the media does not simply reflect the world, but also organises and delivers a specific narrative through its practices; what Stuart Hall defines as engaged in the "politics of signification" (1985). Through these practices, the media produces certain narratives and not others, and gives events certain meanings and not others. There is a large consensus amongst critical scholars that the press, television, radio and the Internet count amongst the most important places in which ideological struggles over meaning take place (Althusser 1971, Gramsci 1971, Thompson 1984, Hall 1985) to discern what is acceptable and what it is not, what is normal and what is deviant, what is right and what is wrong.

Some media scholars and professionals are against the idea that the media is instrumental in creating or perpetuating ideology (Ward 1998, Schudson 2001). However, empirical evidence confirms that the media gives us a picture of the public debate on ideas that plays an important role in shaping our social perceptions, thereby having an impact on individual ideas (Golding 1977, Thompson 1995, Patterson \& Donsbagh 1996, Norris 1997, 
Watson 1998, Herman \& Chomsky 2010). Furthermore, the media normalises specific social relations, that is, it promotes certain behaviours while excluding others, and gives certain social relations more power to spread and perpetuate. Underlying this fact is the idea of power being implemented at the level of culture, as well as the notion of ideological domination through the imposition of a hegemonic view (Gramsci, 1971). Ideology, and political ideologies in general, have been addressed from both theoretical and applied perspectives by communication scholars in an attempt to uncover ideology in the media. This has mostly happened with regard to the press, which has been traditionally considered the reference for political debate by the rest of the media (Hall 1977, Altheide 1984, Fowler 1991, Thompson 2013). The main goal has been to reveal whether pluralism is present or absent in the media. However, the complexity of such a task has proven to be high, and has usually led to problems. In the case of quantitative content studies, for instance, the use of positive, neutral and negative categorisations prevents us from getting a deep insight into the underlying images of society portrayed by the media. In the case of discourse and qualitative studies, the results are difficult for other scholars to replicate, and usually their value is problematized because of the high degree of subjective appreciations that are needed to achieve the analytical richness they provide.

Attempts at trying to systematise the study of ideology in the media, to make fruitful and replicable methodological proposals, have been scarce, and mostly ended up with the same problems already mentioned. This paper tries to contribute to the systematisation of the study of ideology in the media by providing a method to analyse political ideologies in media texts. We aim to offer a method which is both replicable and qualitative. Our work has been inspired by previous studies that were mostly conducted in the field of political communication. The method we propose relies on the need to reach a deeper comprehension of the representation of ideology in the media, while at the same time avoiding the problems raised using traditional categories of political ideologies. Thus, the aim is to figure out a tool which is as cross-cultural as possible -so it can be applied to media texts produced in Western democracies - but, at the same time, which is nourished by the rich theoretical modern work which has been done on political ideologies.

To this end, we propose a theoretical-analytical model for the analysis of ideologies in the press. The model is based on an adapted version of Douglas and Wildavsky's (1982) worldviews labelling the media as elitist, egalitarian, individualist or communitarian (or a combination of these). Our adaption is the result of an analysis which includes the core themes and categories of the main traditional political ideologies, but not restricted to them.

The paper is organised as follows: We (i) define ideology and (ii) political ideologies, (iii) conduct a literature review on the research done on political ideologies in the media, mostly in the press; and (iv) describe our method to map the ideology of newspapers, followed by $(v)$ the results of a small research test conducted to check the method and its reliability. 


\section{The concept of ideology}

The conceptual realm of ideology implies, not only understanding the origin of the term, but in particular gathering its vast appropriation and application by different authors in different historical periods and contexts. In this regard, we could cite Žižek: "By way of a simple reflection on how the horizon of historical imagination is subjected to change, we find ourselves in medias res, compelled to accept the unrelenting pertinence of the notion of ideology" $(2012,5)$.

One of the main authors connected to the origin of the term ideology is Karl Mannheim. He points out that, according to the father of empiricism Francis Bacon's (1561-1626) theory of the idola, the term idols "may be regarded to a certain extent as a forerunner of the modern conception of ideology" (Mannheim 1954, 55). However, the term ideology is widely attributed to the soldier, politician and philosopher Antoine Louis Claude Destutt (1754-1836) (Eagleton 1991; Wright \& Eatwell 1993; Bauman 1999; Eccleshall et al 2003; Freeden 2003; Hawkes 2003; Mészáros 2005, Vincent, 2010; Heywood, 2012), commonly found in the literature just as Destutt de Tracy, who towards the end of the $18^{\text {th }}$ century concentrated on organising "an approach to understanding how ideas are formed" (Sargent 2009, 6) or in creating a "science of the ideas" (Stankiewicz $1993,247)$. The term was coined by joining the Greek nouns eidos (that which is seen, form, shape) and logos (word, statement, speech) (Liddell \& Scott 1940). In the spirit of the Enlightenment, Destutt de Tracy organised a system for the analysis of ideas following Condillac's model of perceptual cognition (Gaukroger 2015, 393). At that same time, since some of the French philosophers were hostile to Napoleon's regime, the French military leader used the term ideology in "a depreciative way to define his opponents as sectarian and dogmatic" (Abbagnano 2007, 531). As pointed out by Schwarzmantel (1998), the term arose with the ascension of the modern state, civil society and the new agenda of political thought.

In spite of this original shaping, the word ideology did not settle solidly in history until it was incorporated by Karl Marx (1818-1883) in a work written with Friedrich Engels (1820-1895), The German Ideology (1845-6), where they composed the integral theory of historic materialism and criticised a set of political illusions (Tower Sargent 2009) -also considered metaphysical, here building a critique specifically of Feuerbach's (1804-1872) philosophical thoughts on the nature of man. In Marx and Engels' work, the term ideology appears connected with the idea of men's life process and their material conditions of production and alongside that, the production of consciousness (Marx \& Engels 1975, 36-37) -that is, a crucial notion for critical studies of the media and the press. Attributed to Engels when writing a letter to Franz Mehring in 1893, the use of the term falseconsciousness is important within Marxist theory and in the evolving discussion of ideology among many theorists. The term was used in order to explain how Engels understood individuals developing their own thought within the frontiers of their own reality and social-cultural heritage -building a personal picture of the world which is necessarily incomplete.

Despite the fact that the meaning of ideology in Marx's works is considered to experiment variations according to some authors (Seliger 1979; Vincent 2010), his and Engels' contribution is essential for the comprehension of a world organised by ideas and concepts as the determining principles of "real life-process" (Marx \& Engels 
1976, 36). Even though, as Wright \& Eatwell (1993) pointed out, Marx himself did not considered his own political views as "ideology".

Pre-war and post-war periods were times characterised by intense discussion around political ideas (Freeden 2006). From the birth of the term in the $18^{\text {th }}$ century, and crossing the turbulent $19^{\text {th }}$ and $20^{\text {th }}$ centuries intensely marked by wars and revolutions, as well as by the origins of major social changes- ideology has always been invoked in times of conflict. It happened when Gramsci (1892-1937), imprisoned from 1926 to 1933 by the Italian Fascist regime, wrote prominently on the idea of hegemony. Based on the Marxist understanding of ideology, and the concept of the ruling class, Gramsci "offers an account of the way that ruling ideology is produced, maintained and reproduced" (Lloyd 2003, 231); particularly, on the cultural aspects that explain inequality in the world. As Tower Sargent (2009) pointed out, Gramsci developed the aspects covered by ideology when choosing to look at the dispute between groups and their battle to settle their own ideas as dominant ones. Also, Gramsci sees ideology "deeply embedded in all language and culture" (Vincent 2010, 6). Another prominent theoretician of ideology is the above-mentioned Karl Mannheim. When summarising the main theories of ideology, Tower Sargent indicates that Mannheim also contributes with the notion of reality and democracy, proposing that individuals deal with ideology from two perspectives: total conception, and particular conception $(2009,7)$. In Ideology and Utopia - An Introduction to the Sociology of Knowledge, Mannheim explains that "total conception" is related to beliefs shared by a group, while "particular conception" relates to the point when one recognises others' beliefs as opposed to their own, not recognising their own ideas as ideological and classifying the others' beliefs as false $(1954,55)$.

In the 1960s, ideology was also used as a concept to analyse social action and life, including the political sphere and beyond (Heywood 2012). The notion of a "neutral concept" of ideology was subject to criticism, for being "so bland and generalised that it loses its critical edge", according to Heywood $(2012,10)$. Moving towards the end of $20^{\text {th }}$ century, the term ideology experimented a shaping process. Although there is a shared understanding that ideology is basically "an essentially contested concept" (Sargent 2009), it is also pointed out that studies on ideologies are rather fragmented, and academically-speaking not integrated, or at least not well discussed among the scholarly community (Leader Maynard 2013). In this context, and rather than theorising in order to attain an unambiguous definition, scholars have been devoted to organising the previous body of knowledge in recent times. For instance, Gerring, after cataloguing the contemporary definitions of ideology, suggested a framework containing all "attributes regularly associated with ideology" (1997, 958-959). He also alerted that the "neologisms" created by some social science scholars who were intrigued by the impairment when defining ideology, "fail to capture the political connotations of ideology" (Gerring 1997, 961). Leader Maynard (2013), on the other hand, put together an important work organising the contemporary studies that have analysed ideology over the past two decades by scope of research. He points out three "broad categories": conceptual approaches, discursive approaches, and quantitative approaches, and proposes a "map of the field", as defined by the author himself (Leader Maynard 2013, 299). Consequently, authors studying ideologies talk about a post-ideological time, the crisis of ideology, or the end of ideology (Schwarzmantel 1998; Freeden 2003, 2006; Lloyd 2003; Tower Sargent 2009; Heywood 2012) -that is, terms that emerged in the Cold War (Vincent 2010). Mostly, 
authors agree on the necessity of constantly reviewing the role of political ideologies in the contemporary world. However, when discussing the possibility of the end of ideology, critics can also be found -as in the case of Žižek, who labelled this idea as "naïve" and "following utilitarian motivation for late-capitalists" (2012, 34-35). Finally, the most recent reflections about ideology are connected to the notion of the global market and capital, as defined by Hawkes in his book chapter "Ideology after 11 September" $(2003,180)$. The author sketches a necessary scrutiny of the connections between political power, global markets, social classes, human labour and the construction of ideological narratives. As Mészáros summarises: "The plain truth is that in our societies everything is 'soaked in ideology'"' $(2005,62)$.

From the different approaches to ideology summarised above, it is apparent that authors have built a solid theorisation that allows for the concept of ideology to be adopted by scholars who study the term in connection with other societal phenomena, such as culture, religion, and politics. This leads us to the more specific notion of political ideologies.

\section{Political ideologies in the social sciences}

The notion of political ideologies is also subject to a diversity of approaches. These approaches can be identified in the scholarly efforts made by authors such as Eatwell \& Wright (1993), Schwarzmantel (1998), Eccleshall et al (2003), Freeden (2003), Tower Sargent (2009), Vincent (2010), Heywood (2004, 2011, 2012), Freeden, Tower Sargent \& Stears (2013), and Ball, Dagger \& O'Neill (2014). All of them put together the body of political thought that may be included in each ideology, and all of them have discussed, classified and gathered ideas under different sets of political ideologies. Despite their differences, these authors acknowledge that political ideologies change over time, and this implies a constant reconsideration of the principles (Tower Sargent 2009). Freeden, for instance, provides one of the most comprehensive definitions of political ideology:

"A set of ideas, beliefs, opinions, and values that (1) exhibit a recurring pattern, (2) are held by significant groups, (3) compete over providing and controlling plans for public policy and (4) do so with the aim of justifying, contesting or changing the social and political arrangements and processes of a political community" $(2003,32)$

This definition is interesting because of the general concept of ideology brought into this context. Although the notion of power is relevant to understand the functioning of political ideologies, the latter can be approached from other viewpoints. Heywood, for instance, adds that political ideologies:

"(a) Offer an account of the existing order, usually in the form of a 'world view'; (b) advance a model of a desired future, a vision of the "good society"; (c) explain how political change can and should be brought about -how to get from (a) to (b)" $(2012,11)$. 
Thus, political ideologies are also understood as more than just an endeavour for power or "mere propaganda" (Heywood 2012), that is, something that goes beyond "an attempt to shape how people think -and therefore how they act"(Ball, Dagger \& O'Neil 2014, 5). Rather, they are also considered as a "complex causal interaction of cognitive, affective and social factors" (Leader Maynard 2013, 343) grounded on the "study of substantive, concrete configurations of political ideas that matter to, and in, societies" (Freeden 2006, 15) and "not synonymous with the dogmatic or fanatical [everyday use]" (Eatwell \& Wright 1993, ix).

Recent proposals regarding political ideologies vary significantly. It is important to remark that, as a rule, the authors' working countries or regions determine how the units that are being considered in each set of political ideologies are defined. One should therefore be careful with the dominant approaches -that is, American and European traditional sets of ideologies - and the extent of their viability for other countries and regions. In this respect, and in order to propose a methodological approach to study the press, it is necessary to avoid narrow sets of ideologies. To build a comprehensive catalogue of political ideologies, we suggest the work of a number of authors defining political ideology sets -including Eatwell \& Wright (1993), Schwarzmantel (1998), Eccleshall et al (2003), Tower Sargent (2009), Vincent (2010), Heywood (2012), Freeden, Tower Sargent \& Stears (2013), and Ball, Dagger \& O'Neill (2014). These authors stand out for their researching and publishing background in the subject, as well as for their permanent review of the sets in keeping with recent international political scenarios and tendencies. With respect to the eight works selected, not all the authors agree on one definitional set of political ideologies, hence a wide variation was found. However, some political ideologies are indicated by more than one author, as illustrated in Figure 1.

Figure 1: Most cited political ideologies in literature

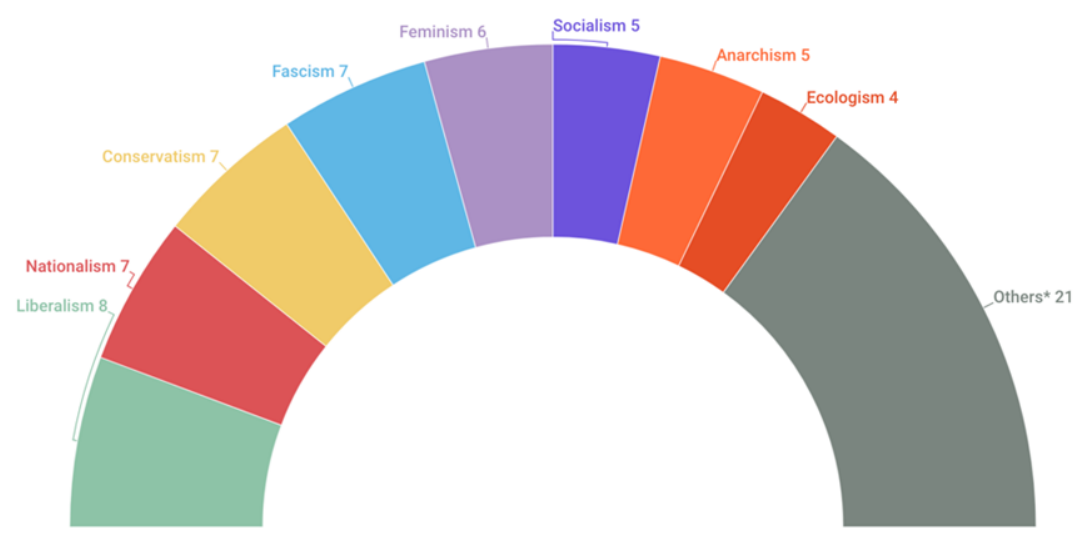

Source: Elaborated by the authors based on Eatwell \& Wright (1993), Schwarzmantel (1998), Eccleshall et al (2003), Tower Sargent (2009), Vincent (2010), Heywood (2012), Freeden, Tower Sargent \& Stears (2013), and Ball, Dagger \& O'Neill (2014). 
Table 1: List of the 21 other political ideologies cited only one time each in the literature reviewed

\begin{tabular}{|l|l|}
\hline Globalisation & Tower Sargent (2009) \\
\hline Christian Democracy & Freeden, Tower Sargent \& Stears (2013) \\
\hline Social Democracy and Democratic Socialism & Eatwell \& Wright (1993) \\
\hline Conservatism (The right) & Schwarzmantel (1998) \\
\hline Democracy (D. Capitalism and D. Socialism) & Tower Sargent (2009) \\
\hline Marxism and Communism & Eatwell \& Wright (1993) \\
\hline Social Democracy & Freeden, Tower Sargent \& Stears (2013) \\
\hline Communism & Freeden, Tower Sargent \& Stears (2013) \\
\hline Marxism & Tower Sargent (2009) \\
\hline Economic Libertarianism & Freeden, Tower Sargent \& Stears (2013) \\
\hline Green Ideology & Freeden, Tower Sargent \& Stears (2013) \\
\hline Fundamentalism & Vincent (2010) \\
\hline Religious Fundamentalism & Heywood (2012) \\
\hline Libertarianism (Minimalism) & Tower Sargent (2009) \\
\hline Ideology and Utopia (Utopianism) & Freeden, Tower Sargent \& Stears (2013) \\
\hline National Socialism & Tower Sargent (2009) \\
\hline Environmentalism & Tower Sargent (2009) \\
\hline Populism & Freeden, Tower Sargent \& Stears (2013) \\
\hline Republicanism & Freeden, Tower Sargent \& Stears (2013) \\
\hline Ideologies of Empire (Imperialism) & Freeden, Tower Sargent \& Stears (2013) \\
\hline Multiculturalism & Heywood (2012) \\
\hline Sorce: & (1993), Scharmant (199) Ecc \\
\hline
\end{tabular}

Source: Elaborated by the authors based on Eatwell \& Wright (1993), Schwarzmantel (1998), Eccleshall et al (2003), Tower Sargent (2009), Vincent (2010), Heywood (2012), Freeden, Tower Sargent \& Stears (2013), and Ball, Dagger \& O’Neill (2014).

The only political ideology which is cited by all eight authors is Liberalism. Nationalism was addressed by seven of them (Eatwell \& Wright; Schwarzmantel; Eccleshall et al; Tower Sargent; Vincent; Heywood; Freeden, Tower Sargent \& Stears), and the same can be said about Conservatism and Fascism (Eatwell \& Wright; Eccleshall et al; Tower Sargent; Vincent; Heywood; Freeden, Tower Sargent \& Stears; Ball, Dagger \& O'Neill). Feminism appears in six out of the eight works consulted (Eatwell \& Wright; Eccleshall et al; Tower Sargent; Vincent; Heywood; Freeden, Tower Sargent \& Stears), whereas five works address Socialism (Schwarzmantel; Eccleshall et al; Vincent; Heywood; Ball, Dagger \& O'Neill) and Anarchism (Eatwell \& Wright; Tower Sargent; Vincent; Heywood; Freeden, Tower Sargent \& Stears). Ecologism is cited by four authors (Eatwell \& Wright; Eccleshall et al; Vincent; Heywood).

These reference works also include twenty-one additional political ideologies, which were addressed by one single author each: Globalisation, Christian Democracy, Social Democracy and Democratic Socialism, 
Conservatism (also labelled as "The Right" by Schwarzmantel), Democracy (sub classified as "Democratic Capitalism" and "Democratic Socialism" by Tower Sargent), Marxism and Communism, Social Democracy, Communism, Marxism, Economic Libertarianism, Green Ideology, Fundamentalism, Religious Fundamentalism, Libertarianism (also explained by Tower Sargent as "Minimalism"), Utopianism, National Socialism, Environmentalism, Populism, Republicanism, Ideologies of Empire (also used by Freeden, Tower Sargent \& Stears as "Imperialism") and Multiculturalism.

In all cases, authors propose a set of political ideologies on a well-grounded basis. They explain the reasons to include or classify some ideologies, or exclude others, and the denomination and definition they propose for each one. Of course, there is a certain level of disagreement amongst authors, with Eatwell \& Wright (1993) standing out by discussing what ideology is and is not. They indicate for example the use of the terms 'democracy' and 'capitalism' being usually confused with "governmental and economic procedures or systems" (Eatwell \& Wright, 1993, 6). The case of globalisation could also be cited, supported by Freeden, that does not represent an ideology "but a political and economic process that can denote the breakdown of political borders and of the realm of states; or the spread of certain production and consumption practices across the world" $(2010,95)$. Tower Sargent embraces a different position about the term, suggesting that globalisation, together with anti-globalisation movements, may be considered a new or "thin" ideology $(2009,49)$.

In any case, a proposal for the mapping of the press from the viewpoint of political ideologies must take into account the number of ideologies to be considered. In this respect, an excessive amount of sets of political ideologies could lead to conceptual overlapping that might complicate the operationalisation of analytical variables and categories. Tower Sargent's (2009) fourteenth edition of Contemporary Political Ideologies - A Comparative Analysis presents a long list (12) of contemporary political ideologies: Nationalism, Globalisation, Democracy (democratic capitalism and democratic socialism), Conservatism, Liberalism, Feminism, Marxism, Anarchism, Libertarianism, Fascism, National Socialism and Environmentalism. The same author -alongside Michael Freeden \& Marc Stears (2013) in The Oxford Handbook of Political Ideologies- propose an even longer list (15): Conservatism, Christian Democracy, Liberalism, Social Democracy, Communism, Anarchism, Economic Libertarianism, Green Ideology, Ideology and Utopia (Utopianism), Nationalism, Fascism, Populism, Republicanism, Ideologies of Empire (Imperialism) and Feminism. On the other hand, the shortest sets of political ideologies are found in Schwarzmantel (1998) and Ball, Dagger \& O'Neill (2014). The first author lists four ideologies: Liberalism, Socialism, Conservatism, and Nationalism. Ball, Dagger \& O'Neill also list Liberalism, Conservatism, and Socialism, but they include Fascism, and exclude Nationalism. Numerically, the sets depend on the viewpoint of the authors. It is also worth pointing out that the main difference regarding the different sets relies on the idea of organising "classical ideologies" (such as Liberalism, Conservatism, Socialism, Nationalism, Anarchism, Fascism), or adding "new ideologies" (Feminism, Ecologism, Religious Fundamentalism, Multiculturalism), as stated by Heywood $(2012,18)$-"new" in the sense of leaning towards culture, as well as identifying politics providing a range of ideological options and changing from "universalism to particularism", also considering "hybrid ideological constructs" (Heywood 2012, 20-21). In a context in which political ideologies like Liberalism and Conservatism are remarkably recurrent, Eatwell \& Wright (1993), Eccleshall et al (2003), 
Vincent (2010), and Heywood (2012) are the authors that form a corpus of political ideologies with greater similarities.

Interestingly, whereas the discussion about the definition of the term ideology can be grounded on a plurality of views -including traditional and modern approaches- the above-mentioned reference works are all grounded on the same humanistic liberal perspective. This is because the mainstream approach in current political sciences is biased towards English-speaking academic regions grounded on humanistic and liberal values. Thus, it can be an enriching exercise to consider alternative views that may challenge this dominant approach. For instance, there is a strong current of thought challenging not only liberal views but also our human-centric approach to the world. This criticism challenges anthropocentrism and has made a consistent claim of a new ideology leaning towards culture that is completely missed by the dominant liberal approach: speciesism. Speciesism is consistently defined by an increasing set of social scientists as an ideology based on a core idea: that it is justifiable to give preferences to beings simply on the grounds that they are members of the homo sapiens species (Singer 2003). The assumption that humans are superior to all other species of animals -and are, therefore, justified in exploiting them for their own use- has had enormous consequences for non-human animals as well as for the planet and humans themselves. For an increasing number of authors, speciesism, or more particularly speciesist anthropocentrism, represents the most pervasive and widely held shared beliefs in society (Nibert 2002), a complex of institutions, discourses and affects that structure humane existence on a "false pathological reality" (Weizenfeld \& Joy 2014, 20-21). This "false, pathological reality" indoctrinates people in the rightness of exploiting the Earth and its non-human inhabitants for human interest alone and, according to the Marxian views in this field, it is the true ideological cement that sustains current capitalism (Best 2014). Because of the wide acceptance of new ideologies (which are new not because the ideologies are new, but because they were not accepted as ideologies until very recently) that go beyond classical ideologies and include a more cultural, transversal impact, speciesism is a natural add-on in any updated list of political ideologies and of a critical expanded view of them, following feminism and environmentalism.

\section{Political ideologies in the media}

Regarding the more specific relationships between political ideologies and communication, it must be noted that the study of the ideological dimensions of the media has been addressed from different viewpoints. The issue has received most attention probably from the critical perspectives of Cultural Studies and the Political Economy of Communication, which were greatly inspired by the Frankfurt School's critical theory and Gramsci's approaches to ideology. Both critical perspectives regarding media and communication are amongst the earlier attempts to study media ideology (Mattelart and Mattelart 1997, 54-73). Within the Political Economy of Communication and Culture tradition, there is an extensive, prolific literature in English that considers the media as a tool for ideological manipulation: examples include the texts of Schiller (1973), Garnham (1986), Chomsky (1989, 2002), Golding and Murdock (1996), and Chomsky and Herman (2002), which are now considered classics. Golding and 
Murdoch's affirmation that the primary raison d'être of the media is to sell, ideologically speaking, the economic, political and social system (i.e. the status quo) consolidates a tradition that has its roots in some of the most prominent Marxist authors in their writings about ideology (Althusser 1971, for example). Non-English-speaking scholars have also contributed to the reflection on ideology in the media from a political economy perspective (Mattelart \& Siegelaub 1983; Martín-Barbero 2002, 52-55-56; Reig 2004; Pineda 2009).

Within the Cultural Studies perspective, on the other hand, in the UK, the Birmingham School of Cultural Studies provided work with a critical analysis of the concept of ideology as a central theme in which Hall introduces his post-Gramscian vision of hegemony - a term he uses to describe the process of the continuous social renewal of the cultural influence of one class over another. Hall $(1973,1982,1996)$ frames the new cultural hegemony produced by the mass media in the context of institutional, political and economic power relations. According to Hall, the media's function is to draw a simplified map to understand the diverse, complex society we live in, offering forms of classification for all issues. For Hall (1977), the media is not an autonomous organism, but it works within an already dominant power sphere, especially because of its close relations with state institutions. Therefore, on the daily routine of news manufacturing, the media delivers ideological messages embedded in content, and for Hall (1973) texts are extremely symbolic messages. Later, Teun Van Dijk emerged as a prolific, widely cited author in the field of media ideology from the perspective of discourse studies $(1998,2008)$. Van Dijk considers ideology the "basis of the social representations shared by members of a group" $(1998,8)$ and the Critical Discourse Analysis approach he contributed towards creating in the late 1990s-early 2000s has become an important perspective within the field due to its focus on the presence of hidden ideologies and the analysis of power in media discourse.

Aside from general theoretical and methodological approaches to media ideology, there is an ample tradition of empirical studies on the ideological role of the press. To mention only some examples, a conservative, rightwing bias can be found in studies that approach the role of Rupert Murdoch's The Australian as a pioneer of the libertarian right in the second half of the 1970s (McKnight 2003); the ideological role of newspapers like The New York Post (after its purchase by Murdoch in 1977) and The Washington Times in the service of the American right in the final decades of the $20^{\text {th }}$ century and the early $21^{\text {st }}$ century (Brock 2005); or the editorials of the influential writer George F. Will, which reveal a conservative meta-ideology (Goss 2005). On the other hand, a leftist component has been observed in the Norwegian daily Klassekampen (Class Struggle), which has evolved from a Marxist-Leninist-Maoist perspective to left-liberal positions (Rucht 2013). In this context, the tradition of the revolutionary press should also be considered, from the French Revolution to current anti-capitalist Spanish newspapers such as En Lucha (Zhu 2011, 39-41). The ideological analysis of the press has also been conducted on countries that are normally outside the focus of main studies. This is, for instance, the case of Birman \& Lehmann's (1999) research on the strategies used by an influential neo-Pentecostalist church battling for ideological hegemony over the established, and traditionally Catholic, Brazilian scenario; and Dalpiaz's (2008) work studying the content of British newspapers related to the 2006 Brazilian national elections, in order to identify discourse variation according to ideological positions. Non-western countries were addressed in a study by Akhavan-Majid \& Ramaprasad (2000) about the Fourth UN Conference on Women in Beijing to explore the 
influence of dominant ideology on news framing; and by Taiwo (2007), who studied three hundred Nigerian newspaper headlines to unveil hidden ideological meanings.

In addition to the printed press, the analysis of ideological content has also been applied to online-only journalism -that is, newspapers and magazines that are published exclusively online, and that should be differentiated from digital editions of newspapers and magazines that have a hard copy version. In The Republican Noise Machine, Brock (2005), includes a critique of hard-right news sites like the successful WorldNetDaily, currently known as WND. A work by Reig and Labio (2006) focuses on three Spanish-language newspapers (Hispanidad, Rebelión, and Minuto Digital) which are regarded as extremist publications that enhance the prevailing partisanship of mainstream media. From another point of view, Steele's article (2009) about the online newspaper Malaysiakini (Malaysia Now) discusses how an independent news portal can challenge political authoritarianism, while Almiron (2006) performs a structural approach and presents a panorama of insufficiently plural viewpoints in the most widely-read Spanish digital news outlets, with newspapers that are predominantly conservative or ultraconservative. Lastly, Almiron and Pineda (2013) with emphasis on the idea of pluralism, studied opinion columns on Spanish online-only media showing a polarisation characterised by a strong dominance of right-wing views as a main result. However, later work by Labio and Pineda (2016) indicates a lessening of conservative and ultra-conservative dominance, as a result of the rise of left-leaning online-only newspapers and political movements in Spain.

Notwithstanding the abovementioned empirical work, as mentioned in the introduction, the systematisation of a methodology for mapping media ideology is almost unknown. To this respect, the work done by Zunino (2016) is worth mentioning here despite not dealing with political ideologies. Zunino has provided an interesting quantitative approach to analyse the evaluative tone of political press news. This method aims to refine the traditional content analysis model based on "positive", "neutral" and "negative" categories to assess political news. The method aims to integrate processes that have been used in several agenda setting studies with some concepts that are held within appraisal theory. Specifically, Zunino proposes to disaggregate valences and create a more useful, expansive assessment index that is composed of various complementary variables. The aim is to avoid defining valences (neutral, negative, positive) in general, and to identify valences for different issues in order to find out the attitude subsystem behind them. Such an index "does not recognise if the story is only positive or negative, but identifies the different evaluative components and links them on a scale" (Zunino, 2016, 243). Regardless of how fruitful this system may be for content analysis, the method provides little qualitative data beyond the negative/neutral/positive tones, and does not deal with political ideologies. However, the idea of different evaluative components to assess a single article acknowledges the complex set of tensions playing within topics, and the need to consider the varied positions regarding direction or intensity that can be found, not only within a single outlet, but also within a single piece of news.

To sum up, the analysis of media ideology, and press ideology in particular, is a rich research field characterised by the study of different countries and diverse ideological biases. However, these studies approach the media and the press from viewpoints that tend to (a) limit the wide range of existing ideologies to one hegemonic ideology whose features are all-pervading in the culture, (b) focus on a specific political ideology (such as 
conservatism or libertarianism) appearing in specific news outlets, or (c) simply avoid dealing with the complexities of political ideologies. Taking these limitations into account, the goal of this paper is to develop an analytical model that relies on a pluralist view of political ideologies in order to determine ideological tensions amongst and within newspapers, but at the same time avoids the problems and limitations of using traditional political ideologies or one-dimensional scales like the American liberal-conservative axis (McCluskey \& Kim, 2012, 570). This model principally aims to assess the political-ideological bias of journalistic texts and discourses, thus providing a method to identify the political-ideological positioning of an opinion or news piece.

\section{Mapping press ideology: A proposal for an analytical method}

The above-mentioned literature shows at least three main problems with regard to building a catalogue of political ideologies to categorise media outlets. First, classical ideological categories have different meanings to different publics (by way of example, the word liberal is perceived as progressive in the US, centrist in the UK and centre-right-winged in Spain). Second, ideologies are in permanent evolution and do not represent homogeneous sets of beliefs (for instance, socialists traditionally endorsed radical democracy -with high degrees of popular participation and the desire to bring economic life under public control, however, many current social democrats are firmly committed to market capitalism structures). Third, new sets of beliefs have been added to the classical ones (Heywood, 2012, for instance, includes feminists, ecologists, multiculturalists and religious fundamentalists) which, in turn, are not only heterogeneous but also overlap with some classical ideologies (regarding feminism, for example, there are amongst others, separatist feminists, liberal feminists, socialist feminists and ecofeminists; and the latter include at least essentialist ecofeminists and non-speciesist ecofeminists).

Thus, trying to build a catalogue of ideologies to classify the media according to classical labels may run the risk of reproducing cultural biases (either by following the liberal mainstream view or by adopting another cultural perspective), and end up with an unworkable long, overlapping list of ideologies and overlapping categories defining each of them. Therefore, and aiming to figure out a tool which is as cross-cultural and easy to apply as possible, it is suggested here to focus on a reduced set of four general values (individualism, communitarianism, egalitarianism and elitism) and to categorise the media outlets according to them. These general values follow the main categories and theme cores of political ideologies without being constrained by them.

Accordingly, we took the following steps to develop our model:

\section{Step 1: Deconstructing political ideologies}

From the literature review, we identified the most widely accepted old and new political ideologies, their core frames and the ideological markers or key issues embedded in the core frames. The aim was to build on the rich theoretical scholarly work conducted mostly in political science, to gather a comprehensive source of ideas. 
For this purpose, the set of political ideologies organised by Heywood (2012) was considered suitable. On one hand, this choice is justified by the author's scope of selection, which includes both a balanced combination of major ideological traditions - shared by most outstanding political scientists - and, more recently, recognised ideologies accounting for the increased complexity of political concepts in the contemporary world. On the other hand, Heywood's selection is convenient because it considers and emphasises the intersectional points between political ideologies, observing the blurred lines between some of them. Finally, Heywood's regular review and update of the most representative set of political ideologies over 30 years of research makes his set a widelyrecognised proposal.

From this set, we have chosen the aspects that may be more easily traceable in the press output, and we have added a political ideology which was missing in his categorisation. As a result, our model includes the traditional political ideologies of liberalism, conservatism, socialism, anarchism, nationalism and fascism, as well as new systems of thought like feminism, ecologism, religious fundamentalism, multiculturalism and speciesism -the latter being an add-on that complements Heywood's humanistic-liberal bias. At the same time, this approach agrees with Schwarzmantel (1998), who considers it necessary to understand political ideologies and their frequent transformations as a way to handle the diversity of political ideas over time.

Following Heywood, we coincide with the fact that for each political ideology it is possible to identify several core themes, or core frames, since "ideologies seek to prioritise certain values over others, and to invest legitimacy in particular theories or sets of meanings" $(2012,15)$. This is the way each political ideology structures its mental map to explain the social world. These core themes or values are the elements that appear in the political discourse and differentiate each political ideology, thus working as the analytical categories that feed our model. As explained by Van Dijk, "discourses make ideologies observable in the sense that it is only in discourse that they may be explicitly expressed and formulated" $(2005,732)$. The core themes of political ideologies are the analytical construct that enables us to observe the expression and formulation of ideological stances in the press. Bearing in mind the idea that ideologies are understood as belief systems socially shared by members and that mostly operate through discourse, we have used the core themes for each ideology and have disaggregated them into a wider list of key issues aligned with each ideological frame. These key issues work as specific markers that are easily traceable in the press discourse. Accordingly, we have called them ideological markers. These markers work as the empirical concretion of the core frames that underlie each political ideology. Table 2 summarises this concept. The selection of terms included in the column "ideological markers" is extracted from the description of each political ideology found in the specialised literature.

Following the alphabetical order of ideologies (as presented in the Table 2 below), we can see that anarchism is embodied with the core frames of anti-statism, utopianism, anti-clericalism, and economic freedom. This ideology, representing one of the worldviews with greatest critical contestation (Vincent 2010), synthesises the rejection of state power at all levels through the anti-statist theme, and specially its instance of authority. It is characterised by the ideal of a society without any form of subordination to power and coercion by any group over another or over anyone (Tower Sargent 2009). Based on the same idea, the rejection of the power held by the church explains the anti-clericalism value. The ideological marker terms proposed for anarchism are closely 
related to the denial of these power instances. Particularly, the economic vision of anarchists is one cluster that is somewhat of a misfit because, even though it envisions economic freedom, anarchism took different approaches related to an economic proposal both on the far left and the far right of the political spectrum. Anarchism also appears in variations combining different views of other political ideologies, and forming derivative denominations such as collectivist anarchism, anarcho-communism, or anarcho-syndicalism (Franks 2013).

Tradition, human imperfection, organic society, hierarchy and authority, and property are the core frames or themes for conservatism. For this classical political ideology, dating from the $14^{\text {th }}$ century, tradition represents "keeping something intact" (Vincent 2010, 56). Vincent (2010) points out that the use of the term as a simplification of conserving is inappropriate and unhelpful to its comprehension. Tradition is framed here as respect for the previous generations and their social contribution. Even though conservatism has religious roots, some versions of conservatism have lost the argumentation about divine origins throughout history. Contrary to liberalism, conservatism frames the human nature as limited (human imperfection), vulnerable and morally imperfect, hence justifying the importance of a superior social order representing security for the group (O'Sullivan 1993). Consequently, the ideological markers of this political ideology give importance to the construction of an organic society maintained by the role of each component. To provide such social stability, hierarchy and authority are frequently used terms. "Social equality is therefore rejected as undesirable and unachievable; power, status and property are always unequally distributed" as explained by Heywood (2012, 75). Finally, property ownership is reinforced in conservatism as a positive ideal and an action to be encouraged -also as a value to be pursued in order to support the structure for hierarchy and authority.

Newer among the political ideologies set, ecologism is framed by ideas like ecology, holism, sustainability, environmental ethics, and the "from having to being" concept. Ecology is the main core frame because it represents the understanding of living organisms in relation to other organisms and the environment. The ideological markers point at seeking balanced ecosystems and humans being responsible for this endeavour. It provides a less anthropocentric vision about the place of humans on Earth, which represents an "ethical challenge in contemporary political life" (Kenny 2003, 152). Connected to ecology, holism is a core value oriented to see the natural world (the ecosphere) as "an interrelated system" (Vincent 2010). Sustainability is a term used to frame the human responsibility for a non-exploitative attitude and, complementary to it, we find environmental ethics as an orientation to an ethical system where humans are still privileged, but hold a greater concern for the destruction produced by the anthropocentric dominant view. The "from having to being" concept is concerned with the limited availability of natural resources, and embeds a strong critique of materialism and consumerism (Ball, Dagger \& O'Neil 2014).

Fascism is described through the core frames of anti-rationalism, struggle, leadership and elitism, (state) socialism, and ultra-nationalism. Anti-rationalism is one of the main values of the fascist political project, and refers to the will to impulse social action on the one hand, and deny the importance of intellectualism, on the other. The notion of struggle finds its inspiration in "martial values: loyalty, duty, obedience and self-sacrifice" (Heywood 2012, 205) which complements anti-rationalism view and leads to a Darwinist-inspired sense of 
competition. Neglecting equality, fascism promotes elitism and the need for an absolute "supreme leader" (Ball, Dagger \& O'Neil 2014, 199). The socialist element is oriented to build a strong nation above all, referring to social unity and also to economics. The ultra-nationalism value is explained by an ultimate, even fanatic, sense of national unity frequently expressed in the "us vs. them" dichotomy, and consequently "them as enemies" (Wilford 2003, 121). It is important to point out that extreme political projects arose from the ultra-nationalist Fascist model, Nazism being a well-known case.

Included in the group of new political ideologies, feminism has the idea of redefining 'the political', patriarchy, sex and gender, equality and difference as core frames. The main claim of the feminist proposal is a new understanding of public and private politics that redefines 'the political'. The rationale behind this is that the private sphere is highly influenced by a dominant political programme in which women are ignored, excluded or given a secondary role in all major ideologies (Ball, Dagger \& O'Neill 2014, 246). Patriarchy, in turn, defines men's superior power in relation to women, negatively framing sex dominance (men over women) deeply rooted in family and religious traditions. The traditional justification of "natural" gender division is also denied in the feminist political-ideological scheme. It re-establishes the notions of sex and gender: the first is understood as given biological characteristics, and the second as a social and political construct (Bryson 1993, 199). Feminism has different projects according to variations in the understanding of certain values, equality and difference being amongst the main causes of splitting within feminist groups. It can basically be understood as the pursuit of political and economic equality regarding representation, rights and power, and also the desire to "liberate women from difference" (Heywood 2012, 236).

For liberalism, the core frames proposed are individualism, freedom, reason, justice, and tolerance. Inspired by the Enlightenment, the notion of the individual provides a "conception of human beings as fundamentally rational individuals" (Ball, Dagger \& O'Neil 2014, 45) and refers to personal autonomy and the importance of human nature over the social group, although maintaining moral truth as the ideal guidance. Freedom, in turn, refers to the practice of individual freedom of choice, "the choice of where to live, for whom to work, what to buy and so on" (Heywood 2012, 29). The ideological markers related to freedom embrace the hard core of liberalism. Reason is also part of the Enlightenment project and it represents the trust in human capacity to understand the world, and make it evolve devoid of religious views (Vincent 2010). As to justice, it has its markers connected to the notion of individualism, each human being born equal (moral worth) or rights being applied without discrimination (by gender, class, religion, etc.). And lastly, by suggesting balance between the role of individuals and the idea of freedom, tolerance is an important value for liberalism in order to support pluralism.

The core themes of multiculturalism are the politics of recognition, culture and identity, minority rights and diversity. With its origins in Canada, multiculturalism emerges mainly concerned with the rights of minority groups. This political ideology has blurred lines with the major political worldviews, but by means of the politics of recognition it claims legal and political rights for marginalised cultural groups. Culture and identity are the elements that identify and organise social group tenacity. Culture for multiculturalists is "the core feature of personal and social identity" and the tool used for "strengthening their [people's] sense of cultural belonging" (Heywood 2012, 318). When considering minority groups, the ideological markers are related to promoting 
minority rights. On diversity, multiculturalism approximates to nationalism on the shared understanding of "capacity of culture to generate social and political cohesion" (Heywood 2012, 323).

One of the oldest and most powerful forces in politics is nationalism, rooted in the $13^{\text {th }}$ century. It is oriented by the core frames of nation, organic community, self-determination, and culturalism. As its name suggests, the nation is "the central principle of political organisation" (Heywood 2012, 173) for the nationalist project. Shared language, religion and history are the elements that compose the group's identity, and the ideological markers are oriented to affirm identity as primordial for civic order, leading to an organic community. Culturalism, in turn, is connected to the traditions shared by a group as part of their identity, but without surpassing the supreme importance the nation has in this worldview. Self-determination is understood within nationalism as the ideal of common will or "the right to form their own state based on the integrity of their putative nation and to be free from the interference of others" (Finlayson 2003, 100).

Religious fundamentalism is characterised by religions and politics, the fundamentalist impulse, anti-modernism and militancy. The nature of this ideology is the notion of parity between politics and religion. It means that a social group that shares a religious fundamentalist political ideology is organised by belief in a divine or transcendent element, and by the social practices and instances being normalised. The distribution of power in a religious fundamentalist society is also given by a "supreme being" (Heywood 2012, 284). The fundamentalist impulse is understood in the sense of "keeping faith with the original or classical ideas" -in this regard, all political ideologies "contain certain elements of fundamentalism" (Heywood 2012, 287). The anti-modernism value implies that some overlaps occurs with conservatism, regarding its shared notion of non-sympathy for modern ideas. Lastly, a distinctive value of religious fundamentalism is the encouragement towards militancy and commitment attributed to the members, an attitude that sometimes causes conflicts with other religious or non-religious projects. It is important to remark that fundamentalism is not restricted to Islamism, as it is commonly portrayed; on the contrary, there are different religions oriented by this political-ideological scheme. Socialism, which derives from the Latin word sociare, has community, cooperation, equality, class politics and common ownership as core frames. The idea of community is understood as the "implication of the communal and fellowship understanding of the word 'social'"' and offers an idea of unified human beings (Vincent 2010, 83) embodying a collective effort to build and organise society in a fraternal way. Cooperation represents this desirable collective engagement by means of which social bonds, instead of competition, are developed (Geoghegan 2003). Social and economic equality is the value that gives distinctiveness to socialism, and it represents the basis for justice in opposition to the capitalist project of competition and selfish behaviour. Important ideological markers for studying traces of socialist leanings on media content are the ones oriented to the idea of common ownership as a means to achieve equality and redistribution. Redistribution in this case is implemented by the state -the organisation that holds the power to organise the collective and to prevent conflict and instabilities emerging from inequalities (Ball, Dagger \& O'Neill 2014). Lastly, class politics positively frames the representation of unifying class action by mutual identification. This last core frame lost its importance by "consequence of deindustrialisation" and specially because of the narrowing of divisions between classes (Heywood, 2012, 107). 
Finally, the core frames of speciesism that have been selected for our model are anthropocentrism, humananimal dualism, human-centrism, and human exceptionalism or supremacism. The main frames of this ideology are related to the denial of any moral consideration to individuals that are not human, and therefore considered inferior. Speciesist anthropocentrism has largely benefited human beings (Nibert 2003) and denies any need to change how humans treat individuals from other species. This treatment obviously produces huge suffering in billions of non-human animals but also a long list of negative impacts on human society and the environment that are at the roots of current capitalist big failures (Best 2014). To identify speciesism in the press, we suggest using as ideological markers depictions that negatively frame animal activists, that positively frame humans exploiting animals and the exploitation of other animals in general, that forget about non-human animals' interests and objectify them and represent them as dependent on humans (Almiron, Cole \& Freeman 2016).

Table 2: Political Ideologies, Core Frames, and Ideological Markers

\begin{tabular}{|c|c|c|}
\hline $\begin{array}{l}\text { Political } \\
\text { Ideology } 1\end{array}$ & Core Frames ${ }^{2}$ & Ideological Markers ${ }^{3}$ \\
\hline Anarchism & $\begin{array}{l}\text { anti-clericalism, } \\
\text { anti-statism, } \\
\text { economic } \\
\text { freedom, } \\
\text { utopianism }\end{array}$ & $\begin{array}{l}\text { chaos and disorder, direct action, free, autonomous human } \\
\text { beings, natural social order, no economic control, no } \\
\text { management, no political authority, no regulation, perfect society, } \\
\text { radicalism, respect, social solidarity, stateless society, unnecessary } \\
\text { state, unregulated market economy, voluntary agreement }\end{array}$ \\
\hline Conservatism & $\begin{array}{l}\text { authority, } \\
\text { hierarchy, human } \\
\text { imperfection, } \\
\text { organic society, } \\
\text { tradition, property }\end{array}$ & $\begin{array}{l}\text { common morality, faith in God, family traditions, family values, } \\
\text { functionalism, guidance for social actions, hierarchical society, } \\
\text { individual tendency for corruption, national identity, national } \\
\text { loyalty, paternalism, pragmatism, search for security, social } \\
\text { gradation, social justice, social obligations, social order, social } \\
\text { principles, state authority, strong criminal regime, strong } \\
\text { government, traditional mores, traditional practices }\end{array}$ \\
\hline Ecologism & $\begin{array}{l}\text { conservation, } \\
\text { ecology, } \\
\text { environmental } \\
\text { ethics, holism, } \\
\text { sustainability }\end{array}$ & $\begin{array}{l}\text { air pollution, biodiversity, climate change, ecological balance, } \\
\text { ecosystems, environmental organisations, environmental } \\
\text { protection, global warming, natural disasters caused by human } \\
\text { interventions, natural resources, non-human life, preservation, } \\
\text { renewable sources, restoration and/or improvement of the natural } \\
\text { environment, social balance and harmony, soil and water pollution, } \\
\text { sustainable growth, waste management }\end{array}$ \\
\hline Fascism & $\begin{array}{l}\text { anti-rationalism, } \\
\text { elitism, leadership, } \\
\text { state socialism, } \\
\text { struggle, ultra- } \\
\text { nationalism }\end{array}$ & $\begin{array}{l}\text { anti-capitalist, anti-communist, anti-conservative, anti-immigration, } \\
\text { anti-intellectualism, anti-liberal, authority, commitment and faith, } \\
\text { competition natural for human progress, corporatism, duty, } \\
\text { heroism, honour, patriarchy, power, progress, self-sacrifice, state } \\
\text { worship }\end{array}$ \\
\hline Feminism & $\begin{array}{l}\text { equality and } \\
\text { difference, }\end{array}$ & $\begin{array}{l}\text { abortion, anti sex oppression, anti-subordination, body autonomy } \\
\text { and integrity, child sexual abuse, deconstructing gender identities, }\end{array}$ \\
\hline
\end{tabular}




\begin{tabular}{|c|c|c|}
\hline & $\begin{array}{l}\text { redefining 'the } \\
\text { political', } \\
\text { patriarchy, sex } \\
\text { and gender }\end{array}$ & $\begin{array}{l}\text { equal opportunities, equal rights within marriage, female sexual } \\
\text { autonomy, gender equality, gender violence, human rights, LGBT } \\
\text { movements, male dominance, maternity leave, male privileges, } \\
\text { patriarchy, patriarchy dictatorship, prejudice against women, rape, } \\
\text { reproductive rights, sex reassignment surgery, sexual division of } \\
\text { labour, sorority, women's emancipation, women's oppression, } \\
\text { women's rights }\end{array}$ \\
\hline Liberalism & $\begin{array}{l}\text { freedom, } \\
\text { individualism, } \\
\text { justice, reason, } \\
\text { tolerance }\end{array}$ & $\begin{array}{l}\text { autonomous associations, autonomy, civil liberty, constitutional } \\
\text { rules, defined state role (domestic order and diplomatic/external } \\
\text { relations protection), economic liberalism, electoral democracy } \\
\text { (competitive elections), free market, free trade, independent trade } \\
\text { unions, laissez-faire, limited government, majoritarianism, } \\
\text { meritocracy, minimal state, personal development, private } \\
\text { property, self-realisation }\end{array}$ \\
\hline Multiculturalism & $\begin{array}{l}\text { culture and } \\
\text { identity, diversity, } \\
\text { minority rights, } \\
\text { politics of } \\
\text { recognition }\end{array}$ & $\begin{array}{l}\text { affirmative action, citizenship, collective identity, } \\
\text { communitarianism, diversity within unity, equality of opportunity, } \\
\text { ethnic politics, ethnic and cultural nationalism, formal equality, } \\
\text { group self-determination, growing cultural diversity, identity } \\
\text { politics, multicultural public policies, particular group needs, } \\
\text { political liberation, politics of recognition, politics of rights, right of } \\
\text { minority groups }\end{array}$ \\
\hline Nationalism & $\begin{array}{l}\text { culturalism, } \\
\text { organic } \\
\text { community, self- } \\
\text { determination, the } \\
\text { nation }\end{array}$ & $\begin{array}{l}\text { chauvinism, cultural identification, cultural unity, ethnicity, general } \\
\text { will, imperialism, militarism, nation-state, national spirit, } \\
\text { patriotism, racialism, separatism, shared values and traditions, } \\
\text { xenophobia }\end{array}$ \\
\hline $\begin{array}{c}\text { Religious } \\
\text { Fundamentalism }\end{array}$ & $\begin{array}{l}\text { anti-modernism, } \\
\text { fundamentalist } \\
\text { impulse, militancy, } \\
\text { religion as politics }\end{array}$ & $\begin{array}{l}\text { body of unchangeable principles, human world as divine project, } \\
\text { orthodoxy, political position according to religious hierarchy, } \\
\text { rejection of public-private division, religious-political project, } \\
\text { religious organising principles, religious personal conduct, religious } \\
\text { totalitarianism, religious traditions, social regeneration, theocracy }\end{array}$ \\
\hline Socialism & $\begin{array}{l}\text { class politics, } \\
\text { community, } \\
\text { common } \\
\text { ownership } \\
\text { (collectivisation), } \\
\text { cooperation, } \\
\text { equality } \\
\text { (egalitarianism) }\end{array}$ & $\begin{array}{l}\text { capital accumulation, collective activity, cooperative ownership, } \\
\text { economic bubbles, economic efficiency, financial industry, } \\
\text { fraternity, importance of social bonds, material inequalities, } \\
\text { nationalisation, non-productive industries (use-value), progressive } \\
\text { taxation, public ownership, social classes, social democracy, social } \\
\text { justice, social revolution, wealth distribution, working class }\end{array}$ \\
\hline
\end{tabular}




\begin{tabular}{|c|c|c|}
\hline Speciesism & $\begin{array}{l}\text { anthropocentrism, } \\
\text { human-animal } \\
\text { dualism, human- } \\
\text { centrism, human } \\
\text { exceptionalism/ } \\
\text { supremacism }\end{array}$ & $\begin{array}{l}\text { animal activists framed as radicals, terrorists, extremists; humans } \\
\text { exploiting other animals framed as care providers, animal lovers, } \\
\text { victims, conservationists; human use of other animals framed as } \\
\text { normal, natural, equated to progress, needed for economic } \\
\text { growth, human health and ecological balance; other species } \\
\text { framed as commodified or objectified, dependence of humans, } \\
\text { less able, dangerous, a problem; suppression of the animal's } \\
\text { perspective, of the impact on the environment of animal } \\
\text { exploitation, of the intersections with other forms of oppression }\end{array}$ \\
\hline \multicolumn{3}{|c|}{ Source: Elaborated by the authors. } \\
\hline \multicolumn{3}{|c|}{$\begin{array}{l}\text { 1,2 Set of political ideologies and core frames by Heywood (2012) except speciesism (Nibert, 2002; Singer, 2003; } \\
\text { Weizenfeld \& Joy, 2014). }\end{array}$} \\
\hline \multicolumn{3}{|c|}{$\begin{array}{l}3 \text { Ideological markers for each political ideology organised by authors and based on Eatwell \& Wright (1993), } \\
\text { Schwarzmantel (1998), Eccleshall et al (2003), Tower Sargent (2009), Vincent (2010), Heywood (2012), Freeden, } \\
\text { Tower Sargent \& Stears (2013), Ball, Dagger \& O'Neill (2014) and Almiron, Cole \& Freeman (2016). }\end{array}$} \\
\hline
\end{tabular}

\section{Step 2: Identifying what distinguishes political ideologies}

From the previous set of political ideologies, our next task was to identify the most relevant opposed/binary core values emerging from them. The aim was to gather the core issues distinguishing ideologies. The list includes the main elements highlighted by the authors in the literature review as contrasting amongst ideologies. The result is our recommendation of 14 sets of opposed/binary core values as shown in Table 3 . These 14 sets have been included here because they encompass the main traits found in the most important political ideologies as defined in literature. Although some of the pairs are highlighted as opposed views in literature, the list of binary core values suggested here was elaborated by us. 
Table 3: Most relevant opposing core values within political ideologies

1. Hierarchical views vs. Egalitarian views

2. Authority viewed positively vs. Authority viewed negatively

3. Freedom as an individualistic value vs. Other conceptions of freedom

4. Democracy 'from above' vs. Democracy 'from below'

5. State viewed positively vs. State viewed negatively

6. Economy for the individual vs. Economy for the community

7. Society viewed within the egalitarian-elitist framework vs. Society viewed within the individualistcollectivist framework

8. Nation viewed positively vs. Nation viewed negatively

9. Gender viewed as a division vs. Gender not viewed as a division

10. Religion viewed positively vs. Religion viewed negatively

11. Culture viewed positively vs. Culture viewed negatively

12. History as progress vs. History as absence of progress

13. Human-centred view of nature vs. Non-human-centred view of nature

14. Self-centred view of human nature vs. Non-self-centred view of human nature

Source: Elaborated by the authors, drawing mainly from Heywood's core themes (2012), and refined with the literature review (Eatwell \& Wright 1993, Schwarzmantel 1998, Nibert 2002, Singer, 2003, Eccleshall et al 2003, Tower Sargent 2009, Vincent 2010, Freeden, Tower Sargent \& Stears 2013, Ball, Dagger \& O'Neill 2014, Weizenfeld \& Joy 2014, Almiron, Cole \& Freeman 2016).

\section{Step 3. Identifying core themes within the opposed core values}

For each set of opposed core values, different categories or core themes that a coder may effectively find in the news were then identified. Although these categories aim to be comprehensive, they should be taken only as a reference to identify the value under assessment. Table 4 offers the list of categories for each value. These categories include specific topics the coder can find in the news. They represent the translation of the ideological markers of Table 2 into a list of clearly defined themes, in an attempt to systematise the analysis. For a description of each category please see the code book added as annex 1 of this paper. 
Table 4: Main core themes within core values

\begin{tabular}{|c|c|}
\hline 1. Hierarchical view & 1. Egalitarian view \\
\hline $\begin{array}{l}\text { 1.1. Natural inegalitarianism } \\
\text { 1.2. Social inegalitarianism } \\
\text { 1.3. Political inegalitarianism } \\
\text { 1.4. Gender inegalitarianism } \\
\text { 1.5. Speciesist inegalitarianism }\end{array}$ & $\begin{array}{l}\text { 1.6. Natural egalitarianism } \\
\text { 1.7. Social egalitarianism } \\
\text { 1.8. Political egalitarianism } \\
\text { 1.9. Gender egalitarianism } \\
\text { 1.10. Non-speciesist egalitarianism }\end{array}$ \\
\hline 2. Authority viewed positively & 2. Authority viewed negatively \\
\hline $\begin{array}{l}\text { 2.1. Authority from below } \\
\text { 2.2. Authority from above } \\
\text { 2.3. Authoritarian charismatic leadership }\end{array}$ & 2.4. Authority as oppression \\
\hline 3. Freedom as an individualistic value & 3. Other conceptions of freedom \\
\hline $\begin{array}{l}\text { 3.1. Positive freedom } \\
\text { 3.2. Negative freedom }\end{array}$ & $\begin{array}{l}\text { 3.3. Communitarian/Collectivist freedom } \\
\text { 3.4. Inner freedom } \\
\text { 3.5. Absence of individual freedom }\end{array}$ \\
\hline 4. Democracy 'from above' & 4. Democracy 'from below' \\
\hline $\begin{array}{l}\text { 4.1. Elitist democracy } \\
\text { 4.2. Authoritarian democracy }\end{array}$ & $\begin{array}{l}\text { 4.3. Participatory democracy } \\
\text { 4.4. Radical democracy }\end{array}$ \\
\hline 5. State viewed positively & 5. State viewed negatively \\
\hline $\begin{array}{l}\text { 5.1. State as a guarantee of social order } \\
\text { 5.2. State as the embodiment of the common good } \\
\text { and social welfare } \\
\text { 5.3. Authoritarian state }\end{array}$ & $\begin{array}{l}\text { 5.4. Ruling class state } \\
\text { 5.5. Patriarchal state } \\
\text { 5.6. State as evil }\end{array}$ \\
\hline 6. Economy for individuals & 6. Economy for the community \\
\hline $\begin{array}{l}\text { 6.1. Restricted capitalist economy } \\
6.2 \text {. Unrestricted capitalist economy } \\
6.3 \text {. Corporatist economy }\end{array}$ & $\begin{array}{l}\text { 6.4. Community economy } \\
\text { 6.5. Green economy }\end{array}$ \\
\hline $\begin{array}{l}\text { 7. Society viewed within the egalitarian- } \\
\text { hierarchy framework }\end{array}$ & $\begin{array}{l}\text { 7. Society viewed within the individualist- } \\
\text { communitarian framework }\end{array}$ \\
\hline $\begin{array}{l}\text { 7.1. Classist society } \\
\text { 7.2. Patriarchal society } \\
\text { 7.3. Plural society } \\
\text { 7.4. Non-plural society }\end{array}$ & $\begin{array}{l}\text { 7.5. Private society } \\
\text { 7.6. Public society } \\
\text { 7.7. Natural society }\end{array}$ \\
\hline 8. Nation viewed positively & 8. Nation viewed negatively \\
\hline $\begin{array}{l}\text { 8.1. Nations as moral entities } \\
\text { 8.2. Nations as sources of cohesion } \\
\text { 8.3. Nations as the source of meaning } \\
\text { 8.4. Nations as religious entities }\end{array}$ & $\begin{array}{l}\text { 8.5. Nations as artificial divisions } \\
\text { 8.6. Nations as tools of oppression }\end{array}$ \\
\hline 9. Gender viewed as a division & 9. Gender not viewed as a division \\
\hline 9.1. Gender as a positive division & 9.3. Gender as irrelevant \\
\hline
\end{tabular}




\begin{tabular}{|c|c|}
\hline 9.2. Gender as a negative division & \\
\hline 10. Religion viewed positively & 10. Religion viewed negatively \\
\hline $\begin{array}{l}\text { 10.1. Religion as a civil right } \\
\text { 10.1. Religion as a source of cohesion } \\
\text { 10.3. Religion as essential }\end{array}$ & $\begin{array}{l}\text { 10.4. Religion as a distraction } \\
\text { 10.5. Religion as oppression } \\
\text { 10.6. Religion as a competitor }\end{array}$ \\
\hline 11. Culture viewed positively & 11. Culture viewed negatively \\
\hline $\begin{array}{l}\text { 11.1. High culture as a source of self-development } \\
\text { 11.2. Traditions as a source of cohesion } \\
\text { 11.3. Organic monoculture as a distinctive trait } \\
\text { 11.4. Multiculturalism as a source of social cohesion }\end{array}$ & $\begin{array}{l}\text { 11.5. Culture as part of the political } \\
\text { superstructure } \\
11.6 \text {. Culture as a reflection on gender inequality }\end{array}$ \\
\hline 12. History as progress & 12. History as no progress \\
\hline $\begin{array}{l}\text { 12.1. History as progress } \\
\text { 12.2. History as tradition }\end{array}$ & 12.3. History as decay \\
\hline 13. Human-centred view of nature & 13. Non-human-centred view of nature \\
\hline $\begin{array}{l}\text { 13.1. Capitalist view of nature } \\
\text { 13.2. Conservative view of nature } \\
\text { 13.3. Nature as a model } \\
\text { 13.4. Idyllic view of nature } \\
\text { 13.5. Holistic view of nature } \\
\text { 13.6. Divine view of nature }\end{array}$ & 13.7. Non-speciesist view of nature \\
\hline 14. Self-centred view of human nature & 14. Non-self-centred view of human nature \\
\hline $\begin{array}{l}\text { 14.1. Humans as unique individuals } \\
\text { 14.2. Humans as social creatures } \\
\text { 14.3. Humans as part of the ecosystem }\end{array}$ & 14.4. Non-speciesist view of human nature \\
\hline \multicolumn{2}{|c|}{$\begin{array}{l}\text { Source: Elaborated by the authors, drawing mainly from Heywood's core themes (2012), and refined with } \\
\text { the literature review (Eatwell \& Wright 1993, Schwarzmantel 1998, Nibert 2002, Singer 2003, Eccleshall et } \\
\text { al 2003, Tower Sargent 2009, Vincent 2010, Freeden, Tower Sargent \& Stears 2013, Ball, Dagger \& } \\
\text { O'Neill 2014, Weizenfeld \& Joy 2014, Almiron, Cole \& Freeman 2016). }\end{array}$} \\
\hline
\end{tabular}

Step 4. Fitting core themes and values into a simple ideological grid

Finally, we looked for a grid of simple categories in which all the core values and themes could fit. For this reduced set of general values, Douglas and Wildavsky's (1982) grid was chosen and slightly adapted. Therefore, the four big values suggested are individualism, communitarianism, egalitarianism and elitism. The aim was to find a grid on which all the traditional and new political ideologies - and their core themes- could be fitted, to thereby build a comprehensive, but at the same time, very simple and easy to remember framework of analysis. The Douglas and Wildavsky's typology was chosen because it represents two very simple sets of opposed worldviews that embrace all classical and new political ideologies as we can see in Figure 2. The positions on the grid of each political ideology may vary according to our own worldviews, yet all of them can easily be 
located within these four dimensions. For a detailed view of how all the core themes for each ideology fit into each dimension of the grid, please see the code book attached as an annex.

Figure 2: Political ideology and worldviews grid

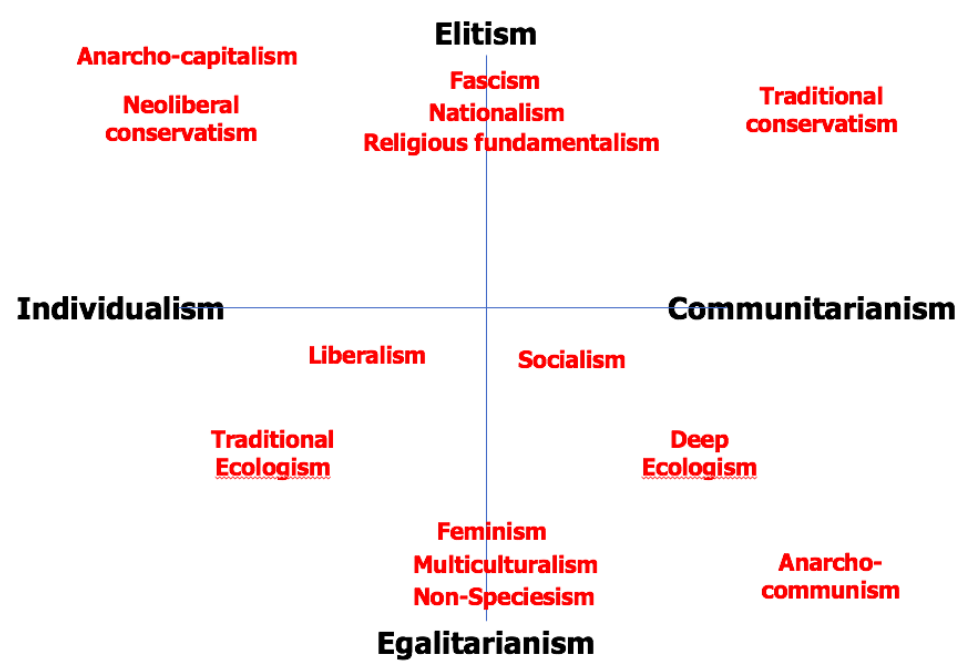

Source: Elaborated by the authors, adapted from Douglas and Wildavsky (1982), and drawing mainly from Heywood's core themes (2012), and refined with the literature review (Eatwell \& Wright 1993, Schwarzmantel 1998, Nibert 2002, Singer 2003, Eccleshall et al 2003, Tower Sargent 2009, Vincent 2010, Freeden, Tower Sargent \& Stears 2013, Ball, Dagger \& O’Neill 2014, Weizenfeld \& Joy 2014, Almiron, Cole \& Freeman 2016).

Media outlets will therefore be able to be labelled as:

- Individualists

- Communitarians

- Egalitarians

- $\quad$ Elitists

(Or any of the various combinations possible amongst the four core values. For instance, in this two-dimensional plane, the intersection of the communitarian and egalitarian dimensions can be understood, in classical ideological terms, as an anarcho-communist stance, while the label of neoliberal conservatism can be placed at the point where individualism and elitism converge).

By means of this analytical model, we suggest a coding procedure that subjects the sample to the following questions:

1) Which is the worldview which dominates? (for instance: elitism)

2) Which core values/frames can be identified from this worldview? (for instance: hierarchical views) 
3) Which core themes are present for each core value/frame identified? (for instance: social inegalitarianism)

4) Which empirical ideological markers frame the core values through the core themes? (this refers to the exact words used in the sample analysed matching our ideological markers)

5) Which ideological label can accordingly be applied to this article? (for instance: elitism, if elitism is confirmed, or a combination of elitism and another worldview)

The point is to collect only the textual examples that include ideological markers which are clearly pointing at the core themes and core values that allow the coder to identify a dominant worldview which can, in turn, be qualitatively scrutinised and deconstructed. Thus, we end with a rather detailed approach to the ideological stance of pieces of news which can contribute to a more objective analysis and understanding.

If so desired, after this procedure, the coder can apply a more specific political ideology label fitting the core values and themes (e. g. neoliberal conservatism, or anarcho-communism) to the analysed sample, although this runs the risk of narrowing the effort for the reasons stated at the beginning of this section. For a discussion of this method we have applied this procedure to a sample of 20 news articles, the results of which are presented in the next section.

\section{Discussion: Mapping the ideology of Spanish online-only newspapers in the case of the 2017 PSOE secretary victory}

In order to apply the method proposed in this article and test its capability and limitations, a small sample of articles was chosen to be analysed. The theme definition to guide the search for articles was the political repercussions of the Spanish Socialist Workers' Party (PSOE) election of a new general secretary that took place on May 215t, 2017; an event known as Primarias Socialistas (Socialist Primaries). This specific event was chosen because of its relevance to the Spanish political scenario. The PSOE is one of the main political parties in Spain, and the May 2017 primary voting was the first election after a period during which the party had been managed by a provisional committee. The committee started managing the party after general secretary Pedro Sánchez resigned on October $1^{\text {st }} 2016$. After a period of turbulence inside the party which was related to other political affairs in Spain, Sánchez was re-elected by the PSOE's rank and file on May $21^{\text {st }}$.

A 20-day time period was established to delimit the search, starting on the election day (May $21^{\text {st }}$ to June $10^{\text {th }}$ ). The resulting sample is composed of 20 articles found in 10 different online-only newspapers: Diariocritico (3 articles), Diario YA (1 article), El Confidencial (2 articles), eldiario.es (3 articles), elplural.com (2 articles), infoLibre (2 articles), Libertad Digital (1 article), Público (2 articles), VoxPopuli (3 articles), and VilaWeb (1 article).

After applying the model, results show that (see Annex 1 for the whole table of results): 
a) 13 articles (65\% of the units analysed) included ideological markers referring to core values in line with egalitarianism or anti-elitism. No opposite core values were found in these articles, and thus we labelled them as holding an egalitarian worldview (6), an egalitarian \& anti-elitist view (6), or an anti-elitist view (1).

b) 7 articles (35\%) included only ideological markers referring to core values in line with elitism or antiegalitarianism. No opposite core values were found in these articles, and so we labelled them as holding an elitist and anti-egalitarian worldview (3), an elitist worldview (3), or an elitist-individualistic worldview (1).

Regarding the way the combinations of worldviews were coded:

- An article was coded as elitist \& anti-egalitarian when it included, for instance, ideological markers justifying, supporting or promoting elitist democracy (core theme 4.1) and a critique of social and political egalitarianism (1.7 and 1.8 respectively) and/or participatory democracy (4.3).

- In contrast, an article was coded as anti-elitist \& egalitarian when it included ideological markers simultaneously providing strong critiques of authority from above (core theme 2.2), to authoritarian democracy (4.2), to elitist democracy (4.1), to classist society (7.1) and to political inegalitarianism (1.3). By way of example, in the case of unit ED03 (in the progressive eldiario.es), the excerpt "Llaman responsabilidad a mantener silencio ante la corrupción y acusan de desorden a quienes exigen cambios" was coded as anti elitist because it clearly included a critique of political inegalitarianism (1.3), social inegalitarianism (1.2), elitist democracy (4.1) and authoritarian democracy (4.2). In the same article, the excerpt "Las elites intentan comprar tiempo, con la esperanza de que mientras tanto, las fuerzas políticas y sociales que buscan un cambio decaigan, pierdan fuelle, se cansen, sean derrotadas" was coded as egalitarian because it supported the core theme of participatory democracy (4.3), and promoted social egalitarianism (1.7) and the state as the embodiment of the common good and social welfare (5.2).

In no cases did the ideological markers contradict each other in the same article, thus no internal inconsistency was found.

In summary, the test conducted applying our method on the sample shows that the online-only Spanish press is rather plural, although a clear majority of articles leaned towards an egalitarian and anti-elitist stance. That is, most of the articles considered the re-election by the militancy of Pedro Sánchez to be fair and democratic, despite the opposition of the party elites, while a minority of articles criticised the re-election because the results went against the party elites, as in the article from El Confidencial(EC02). From such a small sample, obviously, these results cannot be generalised and served only for our purpose of testing the method for mapping ideologies in the press.

From our test, several conclusions can be drawn to increase the reliability of the method. 
First, the test shows that the worldviews used in the analysis very often appear in their negative form. This happens when the article includes ideological markers clearly criticising one specific worldview without expressing direct support for any core value backing the opposite worldview. For those situations, the "anti" prefix was added, because only describing the article in a positive way, as "pro" one worldview, was not accurate enough to consistently represent the article's ideological stance. Our analysis indicates that political ideologies in the press cannot be assessed only positively (for what is supported) but also negatively (for what is opposed), because very often they are expressed in both ways. Thus, the coder must be prepared not to apply worldviews alone but also reactions to opposite worldviews. For example, in one of the articles of the sample ("Doncs a veure ara què farà Sánchez...", from VilaWeb [VW01]), the author did not mention a single explicit egalitarian value directly, but he rather expressed egalitarianism by criticising elitist values.

Second, although the coding process following the method was overall easy and fast to apply, the test confirmed the relevance for the coder of being aware of the author's context and style. This allows misinterpretations to be avoided due to the coder's own point of view. Based on that, the recommendation is always to keep in mind a straight question related to the value that the author is explicitly supporting or criticising, without having to call upon deeper levels of discourse analysis to obtain the answer. A meticulous reading of each piece of content in order to highlight the markers is found to be extremely important.

Third, although one single marker is enough to identify a worldview in an article (if there are no core values that contradict it), the strength of the worldview identified in an article is linked to the number of markers found from the same axis, and to the argumentative consistency related to the markers. In our sample, there was not a single article showing an axiomatic inconsistency, that is, articles including core values that are in total opposition and thus neutralise each other. However, it must be noted that if such a case were found (an article including values which are in blatant contradiction) the coder should discard the article as invalid to determine the author's ideology or, alternatively, it can be considered that the article suffers from some sort of ideological schizophrenia. Fourth, the coding confirms the need to avoid tagging the articles following the traditional classification of political ideologies. As exposed in the theoretical background of this paper, ideology is a very complex theme, as the classification varies according to authors and suffers changes over time. Additionally, some ideologies are marked by blurred lines regarding an assertive -and academically endorsed-delimitation of core values and beliefs, hence requiring a very attentive analysis. The method suggested in this paper contains the core values encompassing the main political ideologies within the four axes adapted from Douglas and Wildavsky's grid (Egalitarianism, Communitarianism, Elitism and Individualism); coders can, if desired, apply the traditional labels of political ideologies (socialism, liberalism, conservatism, etc.) at this stage. However, this tagging cannot be done independently from the coder's own views. In contrast, the method suggested here allows for a pragmatic and efficient representation of ideologies while avoiding the problems of allocating traditional political ideologies. To sum up, we suggest here a qualitative method for mapping press ideology that allows for a high degree of depth and complexity while, at the same time, avoiding the traditional problems of both qualitative and quantitative analysis as well as problems of applying traditional ideological labels -problems of lack of objectivity mostly related to the coder's own worldview. We think that this method might contribute to the field of media 
studies by offering a pragmatic model to objectively systematise the analysis of political ideologies in the press. We encourage researchers to use and refine it.

\section{References}

Abbagnano, N. (2007). Dicionário de Filosofia. São Paulo: Martins Fontes.

Akhavan-Majid, R., \& Ramaprasad, J. (2000). Framing Beijing Dominant Ideological Influences on the American Press Coverage of the Fourth UN Conference on Women and the NGO Forum. International Communication Gazette, 62(1), 45-59.

Almiron, N. (2006). Pluralismo en Internet: el caso de los diarios digitales españoles de información general sin referente impreso. Ámbitos. Revista Internacional de Comunicación (15), 9-31.

Almiron, N., Cole, M. \& Freeman, C.P. (Eds.) (2016). Critical Animal and Media Studies. New York: Routledge.

Altheide, D. L. (1984). Media hegemony: A failure of perspective. Public Opinion Quarterly, 48(2), 476-490.

Althusser, L. (1971). Lenin and philosophy and other essays. New York: Monthly Review Press.

Ball, T., Dagger, R. \& O'Neil, D. (2014). Political Ideologies and the Democratic Ideal. New Jersey: Pearson.

Bauman, Z. (1999). In the search of politics. Cambridge: Polity Press.

Best, S. (2014). The politics of total liberation: Revolution for the 21st century. New York: Palgrave Macmillan.

Birman, P., \& Lehmann, D. (1999). Religion and the Media in a Battle for Ideological Hegemony: The Universal Church of the Kingdom of God and TV Globo in Brazil. Bulletin of Latin American Research, 18(2), 145164.

Brock, D. (2005). The Republican Noise Machine. New York: Three Rivers Press.

Bryson, V. (1993). Feminism. In Eatwell, R., \& Wright, A. (Eds.), Contemporary Political Ideologies (pp. 192215). London: Pinter Publishers.

Checa Godoy, A. (2011). Prensa y partidos políticos durante la II República. Sevilla: Centro Andaluz del Libro.

Dalpiaz, J. (2008). Imprensa e ideologia: a cobertura do governo brasileiro pelos jornais britânicos. Comunicação \& Educação, 13(2), 65-76.

Douglas, M., \& Wildavsky, A. (1982). Risk and Culture: An Essay on the Selection of Technological and Environmental Dangers. Berkeley: University of California Press.

Eagleton, T. (1991). Ideology - An Introduction. London: Verso.

Eatwell, R. (1993). Ideologies: Approaches and Trends. In Eatwell, R., \& Wright, A. (Eds.), Contemporary Political Ideologies (pp. 1-22). London: Pinter Publishers.

Eatwell, R. \& Wright, A. (Eds.). (1993). Contemporary Political Ideologies. London: Pinter Publishers.

Eccleshall, R., Finlayson, A., Geoghegan, V., Kenny, M., Lloyd, M., MacKenzie, I. \& Wilford, R. (2003). Political Ideologies - An introduction Third Edition. London: Routledge.

Fairclough, N. (1989). Language and Power. Harlow: Longman. 
Finlayson, A. (2003). Nationalism. In Eccleshall, R., Finlayson, A., Geoghegan, V., Kenny, M., Lloyd, M., MacKenzie, I. \& Wilford, R. Political Ideologies - An introduction Third Edition (pp. 98-117). London: Routledge.

Fowler, R. (1991). Language in the News: Discourse and Ideology in the Press. London: Routledge.

Franks, B. (2013). Anarchism. In Freeden, M., Taylor Sargent, L. \& Stears, M. (Eds.). The Oxford Handbook of Political Ideologies (pp. 1149-1204). Oxford: Oxford University Press.

Freeden, M. (2003). Ideology: A Very Short Introduction. Oxford: Oxford University Press.

Freeden, M. (2006). Ideology and Political Theory. Journal of Political Ideologies, 11(1), 3-22.

Freeden, M., Tower Sargent, L. \& Stears, M. (Eds.) (2013). The Oxford Handbook of Political Ideologies. Oxford: Oxford University Press.

Gaukroger, S. (2014). Sensibility. In Garret, A. (Ed.), The Routledge Companion to Eighteenth Century Philosophy, (pp. 381-399). London: Routledge.

Geoghegan, V. (2003). Socialism. In Eccleshall, R., Finlayson, A., Geoghegan, V., Kenny, M., Lloyd, M., MacKenzie, I. \& Wilford, R. Political Ideologies - An introduction Thrid Edition (pp. 73-96). London: Routledge.

Gerring, J. (1997). Ideology: A definitional analysis. Political Research Quarterly, 50(4), 957-994.

Golding, P. (1977). Media professionalism in the Third World: The transfer of an ideology. In J. Curran, M. Gurevitch, \& J. Woollacott (Eds.), Mass communication and society (pp. 291-308). London: Edward Arnold Publishers.

Goss, B. M. (2005). "Jeffersonian Poetry": An ideological analysis of George F. Will's editorials (2002-2004). Journalism Studies, 6(4), 417-429.

Gramsci, A. (1971). Selections from the Prision Notebook. London: Lawrence and Wishart.

Hall, S. (1973). Encoding and decoding in the Television Discourse. CCCS Stencilled Paper n. 7. Birmingham: Centre for Contemporary Studies.

Hall, S. (1977). Culture, the media and the "ideological effect". In Curran, J., Gurevitch, M. \& Woollacott, J. (Eds.). Mass Communication and Society (pp. 315-348) London: Edward Arnold Publishers.

Hall, S. (1982). The Rediscovery of 'Ideology': Return of the Repressed in Media Studies. In Gurevitch, M., Bennett, T., and Curran, J. Culture, Society, and the Media (pp. 52-86). London: Methuen.

Hall, S. (1985). Signification, representation, ideology: Althusser and the post-structuralist debates. Critical Studies in Media Communication, 2(2), 91-114.

Hall, S. (1996). Culture, Media, Language: Working Papers in Cultural Studies, 1972-1979. London: Routledge.

Hallin, D., \& Mancini, P. (2012). Comparing Media Systems Beyond the Western World. Cambridge: Cambridge University Press.

Hawkes, D. (2003). Ideology. London: Routledge.

Herman, E. S., \& Chomsky, N. (2010). Manufacturing consent: The political economy of the mass media. New York: Random House.

Heywood, A. (2004). Political Theory - An Introduction. New York: Palgrave Macmillan. 
Heywood, A. (2011). Global Politics. New York: Palgrave Macmillan.

Heywood, A. (2012). Political Ideologies - An Introduction. New York: Palgrave Macmillan.

Kenny, M. (2003). Ecologism. In Eccleshall, R., Finlayson, A., Geoghegan, V., Kenny, M., Lloyd, M., MacKenzie, I. \& Wilford, R. Political Ideologies - An introduction Third Edition (pp. 151-178). London: Routledge.

Klimkiewicz, B. (2005). Media Pluralism: European Regulatory Policies and the Case of Central Europe. EUI Working Papers (RSCAS No 2005/19).

Labio-Bernal, A., \& Reig, R. (2006). Propuestas de comunicación alternativa en Internet: Los casos de Hispanidad, Minuto Digital y Rebelión. Razón y palabra, 49, (pp. 1-10). Retrieved March 5, 2017, from: https://idus.us.es/xmlui/bitstream/handle/11441/28967/Reig\%20y\%20Labio\%20HISPANIDAD.pdf?se quence $=1$ \&isAllowed $=y$

Labio, A., \& Pineda, A. (2016). Leftward Shift, Media Change? Ideology and Politics in Spanish Online-Only Newspapers After the 15-M Movement. International Journal of Communication, 10(2016), 2661-2682.

Leader Maynard, J. (2013). A map of the field of ideological analysis. Journal of Political Ideologies, 18(3), 299327.

Liddell, H. G. \& Scott, R. (1940). A Greek-English Lexicon. Oxford: Clarendon Press.

Lloyd, M. (2003). The end of ideology? In Eccleshall, R., Finlayson, A., Geoghegan, V., Kenny, M., Lloyd, M., MacKenzie, I. \& Wilford, R. Political Ideologies - An introduction Third Edition (pp. 217-241). London: Routledge.

Mannheim, K. (1954). Ideology and Utopia - An introduction to the Sociology of Knowledge. New York: Harcourt. Martín-Barbero, J. (2002). Oficio de cartógrafo. Travesías latinoamericanas de la comunicación en la cultura. México D.F.: Fondo de Cultura Económica.

Marx, K. \& Engels, F. (1975). The German Ideology. In Marx, K. \& Engels, F.: Karl Marx and Friederich Engels Collected Works (vol.5). London: Lawrence and Wishart.

Mattelart A., \& Mattelart, M. (1997). Historia de las teorías de la comunicación. Barcelona: Paidós.

Mattelart, A. \& Siegelaub, S. (1983). Communication and Class Struggle (v. I, II, III). New York: International General.

McCluskey, M. \& Kim, Y. M. (2012). Moderatism or Polarization? Representation of Advocacy Groups' Ideology in Newspapers. Journalism \& Mass Communication Quarterly 89(4), 565-584.

Mcknight, D. (2003). "A World Hungry for a New Philosophy": Rupert Murdoch and the rise of neo-liberalism. Journalism Studies 4(3), 347-358.

Mészáros, I. (2005). The Power of ideology. London: Zed Books.

Nibert, D. (2002). Animal Rights, Human Rights. Lanharm: Littlefield Publishers.

Norris, P. (1997). Politics and the press: The news media and their influences. London: Lynne Rienner Publishers.

O'Sullivan, N. (1993). Conservatism. In Eatwell, R. \& Wright, A. (Eds.), Contemporary Political Ideologies (pp. 50-77). London: Pinter Publishers.

Patterson, T. E., \& Donsbagh, W. (1996). News decisions: Journalists as partisan actors. Political communication, $13(4), 455-468$. 
Pineda, A. \& Almiron, N. (2013). Ideology, Politics, and Opinion Journalism: A Content Analysis of Spanish Onlineonly Newspapers. Triple $C, 11(2), 558-574$.

Rucht, D. (2013). Protest movements and their media usages. In Cammaerts, B., Mattoni, A., \& McCurdy, P. (Eds.). Mediation and protest movements (pp. 249-268). Bristol: Intellect.

Sargent, L. (2009). Contemporary Political Ideologies - A comparative analysis. Belmont: Wadsworth.

Schudson, M. (2001). The objectivity norm in American journalism. Journalism, 2(2), 149-170.

Schwarzmantel, J. (1998). The age of Ideology - Political Ideologies from the American Revolution to Postmodern Times. New York: New York University Press.

Seliger, M. (1979). The Marxist Conception of Ideology. Cambridge: Cambridge University Press.

Singer, P. (2003). Animal liberation at 30. The New York review of books, 50(8), 3.

Smith Pussetto, C., García Vázquez, N. J., \& Pérez Esparza, J. D. (2008). Análisis de la ideología empresarial regiomontana: Un acercamiento a partir del periódico El Norte. CONfines de relaciones internacionales y ciencia política, 4(7), 11-25.

Stankiewicz, W. J. (1993). In search of a political philosophy - Ideologies at the close of the twentieth century. London: Routledge.

Steele, J. (2009). Professionalism Online. How Malaysiakini Challenges Authoritarianism. International Journal of Press/Politics 14(1), 91-111.

Taiwo, R. (2007). Language, Ideology and Power Relations in Nigerian Newspaper Headlines. Nebula 4(1), 218245.

Therborn, G. (1980). The ideology of power and the power of ideology. London: Verso.

Thompson, J. B. (1995). The Media and modernity, a social theory of the media. Cambridge: Polity Press.

Thompson, J. B. (2013). Ideology and modern culture: Critical social theory in the era of mass communication. London: John Wiley \& Sons.

Thompson, J.B. (1984). Studies in the theory of ideology. Berkeley: University of California Press.

van Dijk, T. A. (1998). Ideology: A multidisciplinary approach. London: Sage.

van Dijk, T. A. (2005). Politics, Ideology, and Discourse. In R. Wodak (Ed), Encyclopedia of language \& linguistics: Volume on Politics and Language (pp. 728-740). Amsterdam: Elsevier.

van, Dijk. T. A. (2008). Discourse and power. New York: Palgrave Mcmillan.

Vincent, A. (2010). Modern Political Ideologies. Chichester, UK: Wiley-Blackwell.

Ward, S. J. (1998). An Answer to Martin Bell: objectivity and attachment in journalism. Harvard International Journal of Press/Politics, 3(3), 121-125.

Watson, J. (1998). Media Communication - An introduction to theory and process. New York: Palgrave MacMillan. Weitzenfeld, A \& Joy, M. (2014). An overview of anthropocentrism, humanism, and speciesism in critical animal theory. In Nocella III, A.J., Sorenson, J., Socha, K. \& Matsuka, A. (Eds.), Defining critical animal studies: An intersectional social justice approach for liberation (pp. 3- 27). New York: Peter Lang Publishing.

Wilford, R. (2003). Fascism. In Eccleshall, R., Finlayson, A., Geoghegan, V., Kenny, M., Lloyd, M., MacKenzie, I. \& Wilford, R. Political Ideologies - An introduction Third Edition (pp. 120-150). London: Routledge. 
Zhu, L. (2011). La prensa revolucionaria en la era 2.0 [The revolutionary press in the 2.0 age]. La Hiedra, 1, 3843.

Žižek, S. (Ed). (2012). Mapping Ideology. London: Verso.

Zunino, E. (2016). The assessment of political news in the media agenda: a methodological proposal for more extensive content analysis. Communication \& Society 29(4), 235-253. 